Article

\title{
Xyleborus bispinatus Reared on Artificial Media in the Presence or Absence of the Laurel Wilt Pathogen (Raffaelea lauricola)
}

\author{
Octavio Menocal ${ }^{1, *}$, Luisa F. Cruz ${ }^{1}$, Paul E. Kendra ${ }^{2}{ }^{(\mathbb{D}}$, Jonathan H. Crane ${ }^{1}$, \\ Miriam F. Cooperband ${ }^{3}$, Randy C. Ploetz ${ }^{1}$ and Daniel Carrillo ${ }^{1}$ \\ 1 Tropical Research \& Education Center, University of Florida 18905 SW 280th St, Homestead, FL 33031, USA; \\ luisafcruz@ufl.edu (L.F.C.); jhcr@ufl.edu (J.H.C.); kelly12@ufl.edu (R.C.P.); dancar@ufl.edu (D.C.) \\ 2 Subtropical Horticulture Research Station, USDA-ARS, 13601 Old Cutler Rd., Miami, FL 33158, USA; \\ Paul.Kendra@ars.usda.gov \\ 3 Otis Laboratory, USDA-APHIS-PPQ-CPHST, 1398 W. Truck Road, Buzzards Bay, MA 02542, USA; \\ miriam.f.cooperband@aphis.usda.gov \\ * Correspondence: omenocal18@ufl.edu; Tel.: +1-786-217-9284
}

Received: 12 January 2018; Accepted: 24 February 2018; Published: 28 February 2018

\begin{abstract}
Like other members of the tribe Xyleborini, Xyleborus bispinatus Eichhoff can cause economic damage in the Neotropics. X. bispinatus has been found to acquire the laurel wilt pathogen Raffaelea lauricola (T. C. Harr., Fraedrich \& Aghayeva) when breeding in a host affected by the pathogen. Its role as a potential vector of $R$. lauricola is under investigation. The main objective of this study was to evaluate three artificial media, containing sawdust of avocado (Persea americana Mill.) and silkbay (Persea humilis Nash.), for rearing X. bispinatus under laboratory conditions. In addition, the media were inoculated with $R$. lauricola to evaluate its effect on the biology of X. bispinatus. There was a significant interaction between sawdust species and $R$. lauricola for all media. Two of the media supported the prolific reproduction of $X$. bispinatus, but the avocado-based medium was generally more effective than the silkbay-based medium, regardless whether or not it was inoculated with $R$. lauricola. $R$. lauricola had a neutral or positive effect on beetle reproduction. The pathogen was frequently recovered from beetle galleries, but only from a few individuals which were reared on inoculated media, and showed limited colonization of the beetle's mycangia. Two media with lower water content were most effective for rearing X. bispinatus.
\end{abstract}

Keywords: ambrosia beetle; ambrosia fungi; beetle-fungus symbiosis; Coleoptera; Curculionidae; Lauraceae; Persea americana; Persea humilis; Scolytinae; Xyleborini

\section{Introduction}

Raffaelea lauricola (T. C. Harr., Fraedrich \& Aghayeva; Ophiostomatales: Ophiostomataceae) is a fungal pathogen carried primarily by the redbay ambrosia Xyleborus glabratus Eichhoff (Coleoptera: Curculionidae: Scolytinae) [1,2]. The pathogen is responsible for the vascular disease known as laurel wilt (LW), which affects American members of the Lauraceae family including redbay (Persea borbonia (L.) Spreng), swampbay (Persea palustris (Raf.) Sarg), silkbay (Persea humilis Nash), sassafras (Sassafras albidum (Nutall) Nees), pondspice (Litsea aestivalis (L.) Fernald), pondberry (Lindera melissifolia (Walter) Blume), and avocado (Persea americana Mill.) [1,3-6].

$X$. glabratus is rarely associated with LW-affected avocado trees in commercial plantings in south Florida [7,8]. Previously, the lateral transfer of $R$. lauricola to at least nine of the ambrosia beetle species, in addition to X. glabratus, was demonstrated in Florida $[9,10]$. Moreover, at least two of these 
species, Xyleborus volvulus (F.) and Xyleborus ferrugineus (F.), were shown to experimentally transmit the pathogen to avocado and redbay [9].

Xyleborus bispinatus (Figure 1) was reported in Florida for the first time by Atkinson et al. [11]. Previously, it had not been distinguished from X. ferrugineus, a smaller, morphologically similar ambrosia beetle. Both species have broad distributions throughout South America, Central America, and in the southeastern United States [12,13], and X. bispinatus has also been reported in Italy [14].

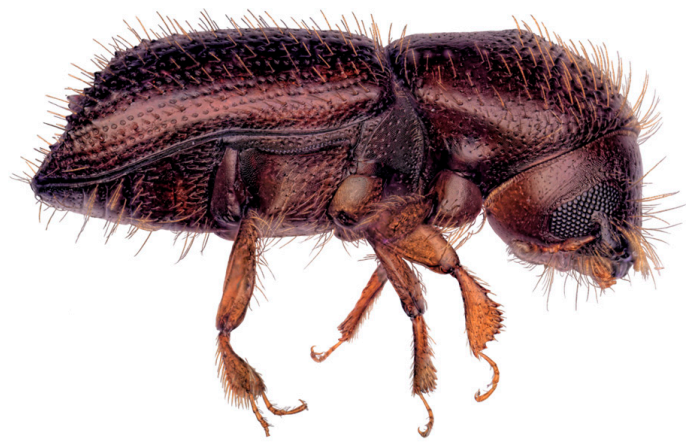

Figure 1. Adult female of Xyleborus bispinatus Eichhoff (lateral view).

Rabaglia et al. [15] stated that X. ferrugineus caused economic damage in lowland areas of the Neotropics. However, there are no supporting data for this statement. In forest ecosystems of central and southern Florida, X. ferrugineus and X. bispinatus occur sympatrically with X. glabratus, with which they reproduce in LW-affected swampbay and silkbay [16,17]. Recently, it has been shown shown that females of X. bispinatus incorporate R. lauricola in their mycangia [10], the storage organs for spores of symbiotic fungi [18]. Although the latter were not distinguished in X. ferrugineus by Carrillo et al. [9], it seems probable that the morphologically similar X. bispinatus can also transmit $R$. lauricola to avocado.

Introduced pathogens have had significant detrimental effects on forest communities. Relevant examples include Cryphonectria parasitica (Murril) M. E. Barr, the causal agent of chestnut blight [19], Cronartium ribicola Fisch, the causal agent of white pine blister rust [20], and Ophiostoma novo-ulmi Brasier, the pathogen that causes the Dutch elm disease [21]. For an increasing number of these diseases, scolytine beetles are vectors of the causal agents [22]. In general, there is limited information on the behavior and biology of these insects. However, with the help of artificial media, it may be possible to improve our understanding of their interactions with host plants and pathogens, as well as their roles in the epidemiology of these diseases.

The first ambrosia beetle species reared on an artificial medium was X. ferrugineus [23]. Since then, agar- and sawdust-based media have been used to rear and study the biology of several other ambrosia beetles [24-28].

Here, we describe a series of studies in which artificial media were evaluated for rearing $X$. bispinatus. The tested media incorporated sawdust from avocado or silkbay and were used to conduct preliminary studies on $X$. bispinatus and its biological response to $R$. lauricola.

\section{Materials and Methods}

\subsection{Artificial Media}

Sawdust from two hosts of X. bispinatus were evaluated. Logs of avocado were collected in February 2016 from an unsprayed avocado orchard in Miami-Dade County, FL $\left(25^{\circ} 29^{\prime} 38^{\prime \prime} \mathrm{N}^{\prime}\right.$ $80^{\circ} 28^{\prime} 53^{\prime \prime} \mathrm{W}$ ), and logs of silkbay were collected in February 2016 from the Archbold Biological Station in Highlands County, FL $\left(27^{\circ} 10^{\prime} 50^{\prime \prime} \mathrm{N} ; 81^{\circ} 21^{\prime} 0^{\prime \prime} \mathrm{W}\right)$. The logs were only used when they were found to be free of beetle infestation. Sawdust was produced as described by Castrillo et al. [29], and the rearing media were prepared as described by Menocal et al. [28]. 
Three types of media were evaluated (Table 1). Medium 1 contained either avocado or silkbay sawdust (hereafter, AM1 and SM1, respectively), as described by Castrillo et al. [29]. The ingredients of Medium 2 and Medium 3 (AM2; SM2 and AM3; SM3, respectively) were described by Biedermann et al. [30], but Medium 3 contained 120\% more water than Medium 2.

Table 1. Three experiments were conducted using ingredients of three artificial media for rearing $X$. bispinatus, using either avocado or silkbay sawdust.

\begin{tabular}{|c|c|c|c|c|}
\hline \multirow[b]{2}{*}{ Ingredients } & \multicolumn{3}{|c|}{ Media } & \multirow[b]{2}{*}{ Manufacturer/Source } \\
\hline & $\begin{array}{c}\text { Type } 1 \text { AM1 } \\
\text { or SM1 }\end{array}$ & $\begin{array}{c}\text { Type } 2 \text { AM2 } \\
\text { or SM2 }\end{array}$ & $\begin{array}{c}\text { Type } 3 \text { AM3 } \\
\text { or SM3 }\end{array}$ & \\
\hline Sawdust & $45 \mathrm{~g}$ & $84 \mathrm{~g}$ & $84 \mathrm{~g}$ & Avocado or silkbay wood \\
\hline Granulated agar & $12 \mathrm{~g}$ & $12.6 \mathrm{~g}$ & $12.6 \mathrm{~g}$ & Difco Agar, Dickinson \& Company, Sparks, MD, USA \\
\hline Sucrose & $6 \mathrm{~g}$ & $2.1 \mathrm{~g}$ & $2.1 \mathrm{~g}$ & Fisher Scientific, Fair Lawn, NJ, USA \\
\hline Starch & $3 \mathrm{~g}$ & $2.1 \mathrm{~g}$ & $2.1 \mathrm{~g}$ & Fisher Science Education, Nazareth, PA, USA \\
\hline Yeast & $3 \mathrm{~g}$ & $2.1 \mathrm{~g}$ & $2.1 \mathrm{~g}$ & Fisher Science Education, Nazareth, PA, USA \\
\hline Casein & $3 \mathrm{~g}$ & $4.2 \mathrm{~g}$ & $4.2 \mathrm{~g}$ & MP Biomedicals, LLC, Solon, OH, USA \\
\hline Wesson's salt mixture & $0.6 \mathrm{~g}$ & $0.52 \mathrm{~g}$ & $0.52 \mathrm{~g}$ & MP Biomedicals, LLC, Solon, OH, USA \\
\hline Tetracycline & $0.21 \mathrm{~g}$ & $0.14 \mathrm{~g}$ & $0.14 \mathrm{~g}$ & Fisher Scientific, Fair Lawn, NJ, USA \\
\hline Wheat germ oil & $1.5 \mathrm{~mL}$ & $1.05 \mathrm{~mL}$ & $1.05 \mathrm{~mL}$ & Frontier Scientific Services, Newark, DE, USA \\
\hline Peanut oil & - & $1.05 \mathrm{~mL}$ & $1.05 \mathrm{~mL}$ & Ventura Foods, LLC, Brea, CA, USA \\
\hline $95 \%$ ethanol & $3 \mathrm{~mL}$ & $2.1 \mathrm{~mL}$ & $2.1 \mathrm{~mL}$ & Decon Labs, Inc., King of Prussia, PA, USA \\
\hline Distilled $\mathrm{H}_{2} \mathrm{O}$ & $370 \mathrm{~mL}$ & $244 \mathrm{~mL}$ & $540 \mathrm{~mL}$ & \\
\hline
\end{tabular}

Type 1 medium from Castrillo et al. [29], using avocado or silkbay sawdust; Type 2 medium from Biedermann et al. [30], using avocado or silkbay sawdust; Type 3 medium from Biedermann et al. [30], using avocado or silkbay sawdust modified with extra water. $\mathrm{AM}=$ Avocado medium; $\mathrm{SM}=$ Silkbay medium.

\subsection{Inoculation of Media}

Twelve tubes of each medium were inoculated with an isolate of $R$. lauricola obtained from $X$. glabratus and identified as described by Dreaden et al. [31]. These tubes, denoted $+\mathrm{RL}$, each received $8.2 \times 10^{6}$ colony-forming units of the pathogen and were incubated at $25^{\circ} \mathrm{C}$ for 10 days.

\subsection{Rearing Conditions and Dissection of Colonies}

The rearing conditions were described by Menocal et al. [28]. Briefly, 12 active and fully sclerotized $X$. bispinatus females were selected from several healthy laboratory stock colonies, originally collected from LW-affected avocado trees. Individual females were dipped in 70\% ethanol for $5 \mathrm{~s}$ to reduce external contaminants and then individually placed into rearing tubes (Figure 2) and incubated in complete darkness at $25 \pm 1{ }^{\circ} \mathrm{C}$ and $75 \% \mathrm{RH}$ (Relative humidity). The surface of the medium and sides of the tubes were inspected every $2-3$ days, and whenever galleries, eggs, larvae, pupae, and adults were first perceived, these observations were recorded (Figure 2).

(A)
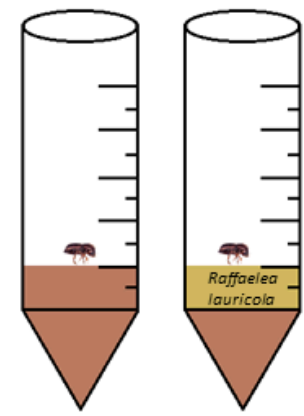

Avocado or Silkbay sawdust media
(B)

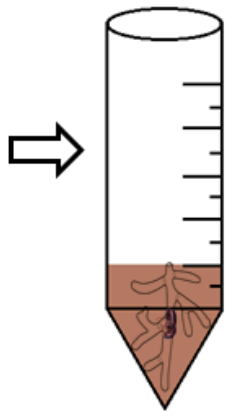

Brood production inside galleries (c)
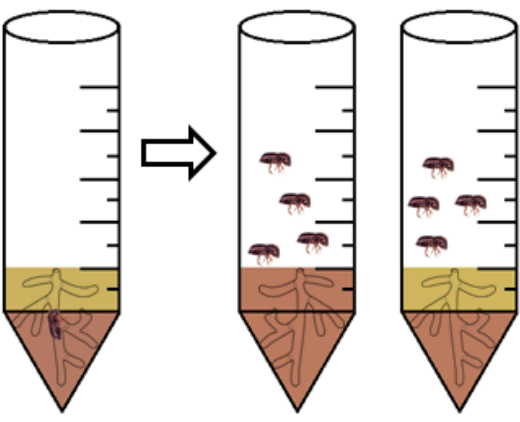

New generation of $X$. bispinatus

Figure 2. Schematic representation of the methodology used to rear X. bispinatus. (A) X. bispinatus females introduced into rearing tubes, (B) 25 days after female introduction), (C) 40 days after female introduction. A detailed description of the rearing methods is presented by Menocal et al. [28]. 
Forty days after female introduction, beetle colonies were destructively sampled in a laminar-flow hood. Different life stages were quantified: first by observing the surface and the sides of the tubes and then by emptying the colony contents into a Petri dish, as described by Cooperband et al. [27]. Eggs, larvae, pupae, and adults were gently removed from the medium and quantified. Motionless adults were recorded as dead, and the foundress female was not tallied. To produce a second generation, 12 fully sclerotized females from each treatment were surface-disinfested for $5 \mathrm{~s}$ in $70 \%$ ethanol and reared as above with the same medium and treatment. The experiment concluded after the emergence of the second generation of females.

\subsection{Fungal Isolation and Identification}

From each - and + RL first- and second-generation tube, one fully sclerotized female was assayed for R. lauricola. Females were surface-disinfested with $70 \%$ ethanol for $30 \mathrm{~s}$ and rinsed three times with sterile deionized water; the heads and bodies were macerated separately in $200 \mu \mathrm{L}$ of sterile water using a motorized tissue grinder (Fisher Scientific Catalog No. 12141361); $100 \mu \mathrm{L}$ of macerate from each body part was then streaked on 9-cm-diameter plates of CSMA medium (cycloheximide, streptomycin, malt and agar), as described by Harrington et al. [32]. The gallery surfaces were sampled with a sterile inoculation loop (Fisher Scientific Catalog No. 22170206) and streaked on CSMA. After 7 days, the colonies that phenotypically resembled the pathogen were quantified and confirmed as R. lauricola with the diagnostic microsatellite markers CHK and IFW of Dreaden et al. [31]. In addition, other fungi which were isolated from the other 12 females and galleries were identified by amplifying a portion of the nuclear large subunit 28S ribosomal DNA, as described by Menocal et al. [28].

\subsection{Data Analysis}

Data were analyzed with two-way analyses of variance (PROC GLIMMIX, SAS v9.3, SAS Institute 2010, Cary, NC, USA). Each medium was evaluated independently and considered a separate experiment. Statistical interactions between sawdust source and - and + inoculation with $R$. lauricola were assessed. Since the data from the first and second generations were similar, they were pooled for the analysis. Data were square root-transformed before analysis to meet the normality assumption. Means were separated statistically with Tukey's HSD.

\section{Results}

\subsection{Medium 1}

Foundress females established first and second generations in all tubes. Eggs were not observed in galleries along the rearing tube walls. However, in AM1 + RL, larvae, pupae, and new adults began to be observed at 12, 15, and 21 days, respectively, after female introduction. In AM1, larvae, pupae, and new adults were observed at 15, 18, and 24 days after female introduction. In SM1 + RL, larvae, pupae, and new adults were observed at 18, 23, and 29 days after female introduction, and in SM1, larvae, pupae, and new adults were observed at 15, 21, and 27.

The interaction between sawdust species and $R$. lauricola was significant $\left(F_{3,95}=18.60, p<0.0001\right)$; total brood and adult female offspring were significantly greater on media containing avocado sawdust (either with or without $R$. lauricola) than on media containing silkbay sawdust (Table 2, Figure 3A). The number of males per brood ranged from zero to four. Males were present in $91 \%$ of AM1 + RL, 88\% of AM1, 79\% of SM1 + RL, and 58\% of SM1. Adult mortality in the colonies was low in all treatments and decreased in the following order: AM1 (7\%), AM1 + RL (6\%), SM1 (5\%), SM1 + RL (3\%). 

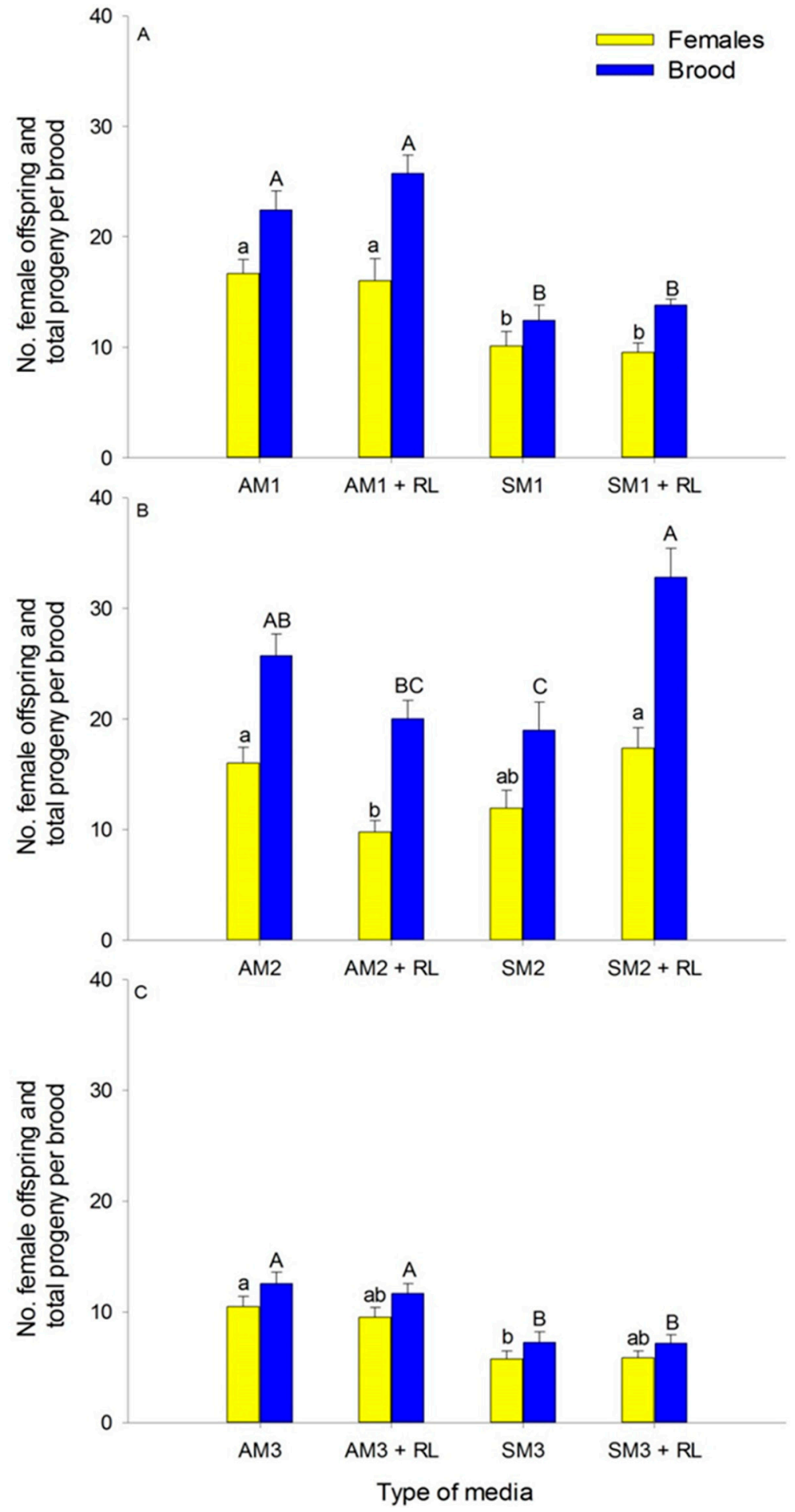

Figure 3. Number of X.s bispinatus female offspring and total brood (including females) produced by one foundress female. Artificial media were (A) (medium 1), (B) (medium 2), and (C) (medium 3), prepared with either avocado (AM) or silkbay (SM) sawdust, and either inoculated (+ RL) or not with Raffaelea lauricola. Bars represent mean numbers of female offspring (yellow) and total brood (blue) produced per foundress \pm SE. For a given medium, offspring and total brood with the same letters are not significantly different (Tukey's HSD test: $p<0.05$ ). 
Table 2. Developmental stages and biological parameters of $X$. bispinatus on medium 1 based on either avocado or silkbay sawdust, either inoculated or uninoculated with $R$. lauricola $(N=24)$.

\begin{tabular}{|c|c|c|c|c|c|c|c|c|c|}
\hline \multirow[b]{2}{*}{ Medium } & \multicolumn{6}{|c|}{ Mean \pm SE of Offspring per Tube after 40 Days } & \multirow{2}{*}{$\begin{array}{c}\text { \% of } \\
\text { Females } \\
\text { per Colony }\end{array}$} & \multirow{2}{*}{$\begin{array}{c}N \text { with } \\
\text { Offspring (Any } \\
\text { Stage) }(\%)\end{array}$} & \multirow{2}{*}{$\begin{array}{c}N \text { with } \\
\text { Females }{ }^{1} \\
(\%)\end{array}$} \\
\hline & Eggs & Larvae & Pupae & $\begin{array}{c}\text { Male } \\
\text { Adults }\end{array}$ & $\begin{array}{l}\text { Female } \\
\text { Adults }\end{array}$ & $\begin{array}{l}\text { Brood (All Stages } \\
\text { Combined) }\end{array}$ & & & \\
\hline AM1 & $0.00 \pm 0.00$ & $4.08 \pm 0.82$ & $0.71 \pm 0.26$ & $0.96 \pm 0.11$ & $16.67 \pm 1.27$ & $22.42 \pm 1.72$ & $74 \%$ & $24(100 \%)$ & $24(100 \%)$ \\
\hline $\mathrm{AM} 1+\mathrm{RL}$ & $0.38 \pm 0.24$ & $5.17 \pm 0.96$ & $2.63 \pm 0.69$ & $1.58 \pm 0.31$ & $16.00 \pm 2.00$ & $25.75 \pm 1.65$ & $62 \%$ & $24(100 \%)$ & $19(79 \%)$ \\
\hline SM1 & $0.17 \pm 0.17$ & $1.21 \pm 0.32$ & $0.25 \pm 0.09$ & $0.67 \pm 0.14$ & $10.13 \pm 1.29$ & $12.42 \pm 1.39$ & $82 \%$ & $24(100 \%)$ & $24(100 \%)$ \\
\hline SM1 + RL & $0.21 \pm 0.15$ & $2.42 \pm 0.60$ & $0.58 \pm 0.19$ & $1.08 \pm 0.18$ & $9.54 \pm 0.86$ & $13.83 \pm 0.53$ & $69 \%$ & $24(100 \%)$ & $21(88 \%)$ \\
\hline
\end{tabular}

AM1 = Avocado medium 1; AM1 + RL = Avocado medium 1 inoculated with $R$. lauricola $;$ SM1 = Silkbay medium 1;

$\mathrm{SM} 1+\mathrm{RL}=$ Silkbay medium 1 inoculated with $R$. lauricola. $N=$ number of rearing tubes used per treatment.

${ }^{1}$ Number of rearing tubes with at least one female offspring.

\subsection{Medium 2}

The percentage of foundress females that established colonies in SM2 + RL, AM2, and SM2, decreased from 100 to 96 from the first to the second generation. In AM2 + RL, foundress females established $100 \%$ of colonies for both generations. During tunnel inspections, no eggs were visible along the galleries through the rearing tube walls. Larvae, pupae, and new adults were observed in galleries visible through the tubes at 12,16, and 21 days, respectively, after a female founder had been introduced into SM2 + RL. In AM2, larvae, pupae, and new adults were observed at 16, 20, and 25 days after female introduction. In the case of AM2 + RL, larvae, pupae, and new adults were observed at 18 , 23, and 29 after female introduction. Finally, in SM2, larvae, pupae, and new adults were visible at 16, 21 , and 25 days after the female foundress was introduced.

There was a significant interaction between sawdust species and the presence of $R$. lauricola $\left(F_{3,95}=13.41, p<0.0001\right)$ (Table 3, Figure 3B). In the avocado sawdust, adult female offspring (but not the total brood) was significantly different in inoculated and not inoculated media. By contrast, in the silkbay sawdust, total brood (but not the adult female offspring) greatly increased in the presence of R. lauricola (Table 3, Figure 3B). The number of males per brood ranged from zero to two. Males were seen in $88 \%$ of the colonies in SM2 + RL, $88 \%$ of AM2, $83 \%$ of AM2 + RL, and 71\% of SM2. As with medium 1, adult mortality was low for all treatments: AM2 (6.6\%), AM2 + RL (5.1\%), SM2 + RL (3.6\%), and SM2 (2.9\%).

Table 3. Developmental stages and biological parameters of X. bispinatus on medium 2, based on either avocado or silkbay sawdust, either inoculated or uninoculated with $R$. lauricola $(N=24)$.

\begin{tabular}{|c|c|c|c|c|c|c|c|c|c|}
\hline \multirow[b]{2}{*}{ Medium } & \multicolumn{6}{|c|}{ Mean \pm SE of Offspring per Tube after 40 Days } & \multirow{2}{*}{$\begin{array}{c}\% \text { of } \\
\text { Females } \\
\text { per Colony }\end{array}$} & \multirow{2}{*}{$\begin{array}{c}N \text { with } \\
\text { Offspring (Any } \\
\text { Stage) }(\%)\end{array}$} & \multirow{2}{*}{$\begin{array}{c}N \text { with } \\
\text { Females }{ }^{1} \\
(\%)\end{array}$} \\
\hline & Eggs & Larvae & Pupae & $\begin{array}{l}\text { Male } \\
\text { Adults }\end{array}$ & $\begin{array}{l}\text { Female } \\
\text { Adults }\end{array}$ & $\begin{array}{l}\text { Brood (All Stages } \\
\text { Combined) }\end{array}$ & & & \\
\hline AM2 & $1.08 \pm 0.36$ & $6.00 \pm 0.99$ & $1.63 \pm 0.31$ & $1.00 \pm 0.17$ & $16.00 \pm 1.42$ & $25.71 \pm 1.94$ & $62 \%$ & $23(96 \%)$ & $23(96 \%)$ \\
\hline SM2 & $0.29 \pm 0.22$ & $4.79 \pm 0.88$ & $1.13 \pm 0.26$ & $0.83 \pm 0.13$ & $11.92 \pm 1.61$ & $18.96 \pm 2.56$ & $63 \%$ & $23(96 \%)$ & $22(92 \%)$ \\
\hline $\mathrm{SM} 2+\mathrm{RL}$ & $2.58 \pm 0.67$ & $8.63 \pm 1.21$ & $3.21 \pm 0.34$ & $1.04 \pm 0.11$ & $17.33 \pm 1.85$ & $32.79 \pm 2.62$ & $53 \%$ & $23(96 \%)$ & $22(92 \%)$ \\
\hline
\end{tabular}

AM2 = Avocado medium 2; AM2 + RL = Avocado medium 2 inoculated with $R$. lauricola $;$ SM2 = Silkbay medium 2;

$\mathrm{SM} 2+\mathrm{RL}=$ Silkbay medium 2 inoculated with $R$. lauricola. $N=$ number of rearing tubes used per treatment.

${ }^{1}$ Number of rearing tubes with at least one female offspring.

\subsection{Medium 3}

The percentage of foundress females that established colonies in AM3 was 100 and 83 in the first and second generations, respectively. In AM3 + RL, 100\% of females established colonies in both generations. In SM3, 85\% of females established colonies in both generations. When using SM3 + RL, the percentage of colony establishment decreased from $100 \%$ to $91 \%$. During gallery inspections, as was the case with medium 1 and 2, no eggs were visible in galleries along the rearing tubes walls. Larvae, pupae, and new adults were first observed at 17, 21, and 25 days, respectively, after the introduction of the female foundress in AM3. In AM3 + RL, larvae, pupae, and new adults were first observed 19, 
22, and 27 days after female introduction. In SM3, larvae, pupae, and new adults were seen at 20, 25, 30 days, and in SM3 + RL at 18, 24, and 28 days after female introduction.

The interaction effect between $R$. lauricola and sawdust species was significant $\left(F_{3,95}=7.57\right.$, $p=0.0001$ ); brood production was significantly greater on avocado sawdust (regardless of inoculation) than silkbay sawdust, with or without $R$. lauricola (Table 4, Figure 3C). Adult female offspring was greater on avocado sawdust than on silkbay sawdust that was not inoculated with $R$. lauricola, but there was no difference when the media of both sawdust species were inoculated with $R$. lauricola (Table 4, Figure 3C). The number of males per colony ranged from zero to three. Males were present in $79 \%$ of the colonies in AM3, 66\% in AM3 + RL, 70\% in SM3, and 66\% and SM3 + RL. Adult mortality was similar in AM3 (5.2\%), SM3 (7.8\%), and SM3 + RL (4.5\%). By contrast, mortality was greater in $\mathrm{AM} 3+\mathrm{RL}(12.9 \%)$.

Table 4. Developmental stages and biological parameters of X.bispinatus on medium 3, based on either avocado or silkbay sawdust, either inoculated or uninoculated with $R$. lauricola $(N=24)$.

\begin{tabular}{|c|c|c|c|c|c|c|c|c|c|}
\hline \multirow[b]{2}{*}{ Medium } & \multicolumn{6}{|c|}{ Mean \pm SE of Offspring per Tube after 40 Days } & \multirow{2}{*}{$\begin{array}{c}\% \text { of } \\
\text { Females } \\
\text { per Colony }\end{array}$} & \multirow{2}{*}{$\begin{array}{c}N \text { with } \\
\text { Offspring (Any } \\
\text { Stage) }(\%)\end{array}$} & \multirow{2}{*}{$\begin{array}{c}N \text { with } \\
\text { Females } 1 \\
(\%)\end{array}$} \\
\hline & Eggs & Larvae & Pupae & $\begin{array}{l}\text { Male } \\
\text { Adults }\end{array}$ & $\begin{array}{l}\text { Female } \\
\text { Adults }\end{array}$ & $\begin{array}{l}\text { Brood (All Stages } \\
\text { Combined) }\end{array}$ & & & \\
\hline AM3 & $0.08 \pm 0.05$ & $1.21 \pm 0.27$ & $0.00 \pm 0.00$ & $0.79 \pm 0.08$ & $10.46 \pm 0.91$ & $12.54 \pm 1.03$ & $83 \%$ & $22(92 \%)$ & $22(92 \%)$ \\
\hline $\mathrm{AM} 3+\mathrm{RL}$ & $0.00 \pm 0.00$ & $1.13 \pm 0.26$ & $0.17 \pm 0.10$ & $0.83 \pm 0.15$ & $9.50 \pm 0.86$ & $11.63 \pm 0.89$ & $82 \%$ & $24(100 \%)$ & $23(96 \%)$ \\
\hline SM3 & $0.04 \pm 0.04$ & $0.58 \pm 0.30$ & $0.17 \pm 0.11$ & $0.71 \pm 0.09$ & $5.71 \pm 0.74$ & $7.21 \pm 0.99$ & $79 \%$ & $20(83 \%)$ & $20(83 \%)$ \\
\hline $\mathrm{SM} 3+\mathrm{RL}$ & $0.00 \pm 0.00$ & $0.42 \pm 0.21$ & $0.21 \pm 0.10$ & $0.67 \pm 0.10$ & $5.83 \pm 0.63$ & $7.13 \pm 0.79$ & $82 \%$ & $23(96 \%)$ & $23(96 \%)$ \\
\hline
\end{tabular}

AM3 = Avocado medium 3; AM3 + RL = Avocado medium 3 inoculated with $R$. lauricola $;$ SM3 = Silkbay medium 3;

$\mathrm{SM} 3+\mathrm{RL}=$ Silkbay medium 3 inoculated with $R$. lauricola $. \quad N=$ number of rearing tubes used per treatment.

${ }^{1}$ Number of rearing tubes with at least one female offspring.

\subsection{Recovery of R. lauricola and Other Fungi from X. bispinatus Reared on Artificial Media}

Adult females reared on + RL carried a low number of colony forming units (CFUs) of R. lauricola (Table 5). R. lauricola was recovered more frequently from females reared on silkbay medium than on avocado-based media (Table 5). Typically, $R$. lauricola was recovered more frequently from the heads than from the bodies (Table 5). The fungus was recovered from 11 out of 24 beetle galleries in AM1 + RL, and from 22 of 24 beetle galleries in SM1 + RL. Similarly, R. lauricola was recovered from 14 of 24 beetle galleries in AM2 + RL, and 15 of 24 beetle galleries in SM2 + RL. Finally, the fungus colonized 14 of 24 beetle galleries in AM23 + RL, and 21 of 24 beetle galleries in SM3 + RL.

Table 5. Recovery and frequency of $R$. lauricola from females of X. bispinatus reared on artificial media previously inoculated with this fungus.

\begin{tabular}{clcccc}
\hline $\begin{array}{c}\text { Medium } \\
\text { Type }\end{array}$ & Host & $\begin{array}{c}\text { Mean No. of CFUs } \pm \text { SE } \\
\text { per Head \& Pronotum }\end{array}$ & $\begin{array}{c}\text { Frequency } \\
(\boldsymbol{n} / \boldsymbol{N})\end{array}$ & $\begin{array}{c}\text { Mean No. of CFUs } \pm \text { SE per } \\
\text { Body Lacking Head \& Pronotum }\end{array}$ & $\begin{array}{c}\text { Frequency } \\
(\boldsymbol{n} / \boldsymbol{N})\end{array}$ \\
\hline \multirow{2}{*}{ Medium 1 } & Avocado & $18.9 \pm 8.9$ & $7 / 24$ & $5.3 \pm 3.3$ \\
& Silkbay & $9.7 \pm 3.0$ & $6 / 24$ & 84 & $3 / 24$ \\
\multirow{2}{*}{ Medium 2 } & Avocado & $6.7 \pm 2.5$ & $6 / 24$ & 20 & $1 / 24$ \\
& Silkbay & $28.9 \pm 10.3$ & $10 / 24$ & 2 & $1 / 24$ \\
\hline \multirow{2}{*}{ Medium 3 } & Avocado & $5.4 \pm 2.9$ & $5 / 24$ & 2 & $1 / 24$ \\
& Silkbay & $6 \pm 1.0$ & $5 / 24$ & $1 / 24$ \\
\hline
\end{tabular}

$n$ : number of individuals testing positive for the presence of $R$. lauricola; $N$ : Number of individuals tested; CFUs: colony-forming units of $R$. lauricola. ${ }^{1}$ Note that each medium was evaluated separately and was considered a separate experiment.

On CSMA, other fungi besides $R$. lauricola were recovered from the heads, bodies, and galleries of $X$. bispinatus reared in avocado and silkbay media (Table 6). Five other species were isolated from colonies inoculated with $R$. lauricola, and six species from colonies not inoculated with $R$. lauricola. Raffaelea subalba (T. C. Harr., Aghayeva \& Fraedrich) was the most abundant and most frequently found fungus, recovered from beetles' heads and bodies in both avocado and silkbay media (Table 6). 
However, in galleries, the most frequent fungus was Raffaelea subfusca (T. C. Harr., Aghayeva \& Fraedrich) (Table 6). Raffaelea arxii T. C. Harr., Aghayeva \& Fraedrich was isolated at a low frequency and abundance. Candida multigemmis (Buhagiar) S. A. Mey \& Yarrow (Saccharomycetales) was isolated from all treatments and only from beetles' heads. Alloascoidea sp. (Saccharomycetales: Alloascideaceae) and Phaeoacremonium inflatipes W. Gams, Crous \& M. J. Wingf (Diaporthales: Togniniaceae) were only isolated from beetle galleries (Table 6).

Table 6. Fungal species isolated from $12 \mathrm{X}$. bispinatus beetles and their galleries collected from either avocado- or silkbay-based media. Fungi were isolated from the head and pronotum or from the body, when head and pronotum were lacking.

\begin{tabular}{|c|c|c|c|c|c|c|c|c|c|c|c|}
\hline \multirow{3}{*}{ Treatments } & \multirow{3}{*}{ Species } & \multicolumn{5}{|c|}{ Medium Containing Avocado Sawdust } & \multicolumn{5}{|c|}{ Medium Containing Silkbay Sawdust } \\
\hline & & \multicolumn{2}{|c|}{$\begin{array}{c}\text { Head } \\
\text { and Pronotum }\end{array}$} & \multicolumn{2}{|l|}{ Body a } & \multirow{2}{*}{$\begin{array}{l}\text { Gallery } \\
\text { Freq. } \\
n / N\end{array}$} & \multicolumn{2}{|c|}{$\begin{array}{c}\text { Head } \\
\text { and Pronotum }\end{array}$} & \multicolumn{2}{|l|}{ Body $^{a}$} & \multirow{2}{*}{$\begin{array}{c}\text { Gallery } \\
\text { Freq. } \\
n / N\end{array}$} \\
\hline & & $\begin{array}{l}\text { Avg. } \\
\text { CFU/Beetle }\end{array}$ & $\begin{array}{l}\text { Freq. } \\
n / N\end{array}$ & $\begin{array}{l}\text { Avg. } \\
\text { CFU/Beetle }\end{array}$ & $\begin{array}{l}\text { Freq. } \\
n / N\end{array}$ & & $\begin{array}{l}\text { Avg. } \\
\text { CFU/Beetle }\end{array}$ & $\begin{array}{l}\text { Freq. } \\
n / N\end{array}$ & $\begin{array}{l}\text { Avg. } \\
\text { CFU/Beetle }\end{array}$ & $\begin{array}{l}\text { Freq. } \\
n / N\end{array}$ & \\
\hline \multirow{6}{*}{$\begin{array}{l}\text { Media } \\
\text { inoculated } \\
\quad \text { with } \\
\text { R. lauricola }\end{array}$} & Raffaelea arxii & 125 & $10 / 12$ & 0 & $0 / 12$ & $0 / 12$ & 70.2 & $7 / 12$ & 0 & $0 / 12$ & $0 / 12$ \\
\hline & Raffaelea lauricola & 4.67 & $3 / 12$ & 0 & $0 / 12$ & $8 / 12$ & 23.8 & $6 / 12$ & 23 & $1 / 12$ & $6 / 12$ \\
\hline & Raffaelea subalba & 474.5 & $11 / 12$ & 0 & $0 / 12$ & $0 / 12$ & 229 & $11 / 12$ & 117 & $9 / 12$ & $10 / 12$ \\
\hline & Raffaelea subfusca & 0 & $0 / 12$ & 0 & $0 / 12$ & $9 / 12$ & 0 & $0 / 12$ & 0 & $0 / 12$ & $0 / 12$ \\
\hline & Phaeoacremonium inflatipes & 0 & $0 / 12$ & 0 & $0 / 12$ & $4 / 12$ & 0 & $0 / 12$ & 0 & $0 / 12$ & $2 / 12$ \\
\hline & Candida multigemmis & 9.1 & $9 / 12$ & 0 & $0 / 12$ & $0 / 12$ & 80.1 & $9 / 12$ & 0 & $0 / 12$ & $0 / 12$ \\
\hline \multirow{7}{*}{$\begin{array}{c}\text { Media } \\
\text { non-inoculated } \\
\text { with } \\
\text { R. lauricola }\end{array}$} & Raffaelea arxii & 40.5 & $9 / 12$ & 0 & $0 / 12$ & $0 / 12$ & 42 & $3 / 12$ & 0 & $0 / 12$ & $0 / 12$ \\
\hline & Raffaelea lauricola & 0 & $0 / 12$ & 0 & $0 / 12$ & $0 / 12$ & 0 & $0 / 12$ & 0 & $0 / 12$ & $0 / 12$ \\
\hline & Raffaelea subalba & 199.7 & $11 / 12$ & 0 & $0 / 12$ & $0 / 12$ & 253.1 & $12 / 12$ & 0 & $0 / 12$ & $0 / 12$ \\
\hline & Raffaelea subfusca & 35.2 & $12 / 12$ & 0 & $0 / 12$ & $10 / 12$ & 0 & $0 / 12$ & 0 & $0 / 12$ & $11 / 12$ \\
\hline & Phaeoacremonium inflatipes & 0 & $0 / 12$ & 0 & $0 / 12$ & $0 / 12$ & 0 & $0 / 12$ & 0 & $0 / 12$ & $4 / 12$ \\
\hline & Candida multigemmis & 37.3 & $10 / 12$ & 0 & $0 / 12$ & $0 / 12$ & 29.7 & $10 / 12$ & 0 & $0 / 12$ & $0 / 12$ \\
\hline & Alloascoidea sp. & 0 & $0 / 12$ & 0 & $0 / 12$ & $6 / 12$ & 0 & $0 / 12$ & 0 & $0 / 12$ & $0 / 12$ \\
\hline
\end{tabular}

${ }^{a}$ Body separated from the head and pronotum. Freq. = Frequency of fungal species detected; Avg. = Average; $n=$ number of beetle body parts or number of galleries that were positive for a fungal species; $N=$ Number of beetles or galleries tested for a specific fungus.

\section{Discussion}

Interactions between plants and insects have promoted insect diversity, but, in many cases, additional factors have enhanced diversification. For example, insect-plant interactions often include microbial associates, some of which are fungal pathogens [22,33]. Ambrosia beetles rely on fungal symbionts to fulfill their nutritional requirements [34,35]. However, the associations among symbiotic fungi and ambrosia beetles remain severely understudied.

The reproduction and survival of ambrosia beetles depends on the growth and quality of fungal symbionts in the colony [36]. Fungal growth, and therefore the reproductive potential of X. bispinatus in this study, may have been influenced by the amount of sucrose, casein, yeast, starch, and water in the media. Robinson et al. [37] found that the sugar content in wood is a significant factor determining fungal colonization by Ophiostoma piceae Munch (Ophiostomatales: Ophiostomataceae). In addition, Abraham et al. [38] found that nitrogen availability affected the growth of O. piceae. Like most Ophiostoma species, O. piceae utilizes ammonium, but not nitrate, as a nitrogen source [39]. Nitrogen is typically scarce in wood $[40,41]$, ranging between 0.01 and $0.1 \%$ of the dry weight. Other ingredients in artificial media, such as yeast and starch, have been reported to be important for ambrosia beetle reproduction. Mizuno \& Kajimura [42] reported more progeny of Xyleborus pfeili (Ratzeburg) in media containing five times more yeast and starch. In this study, reproduction of X. bispinatus was greatest on a medium that contained the most yeast and starch (Medium 1) (Table 1). However, Maner et al. [26] stated that increasing levels of yeast and starch (up to 4 times) did not enhance the reproduction of $X$. glabratus. Interestingly, female mortality increased in the medium with greater levels of these nutrients, yet, when females survived, they produced more brood [26]. Overall, this and other studies suggest that ambrosia beetles (depending on the species) require different amounts of yeast and starch in the rearing media, but that an excess of these substances might result in reduced fitness. Similarly, the amount of water in the media appeared to impact the growth of the symbionts, therefore affecting the beetles' fitness. Although we did not compare the reproduction between the Medium 2 and 
Medium 3 in the present study, females of X. bispinatus produced fewer progeny in the medium with higher water content (Figure 3C).

In this study, several symbiotic fungi were found associated with $X$. bispinatus. Three $R$. species (R. arxii, R. subalba, R. subfusca) were frequently associated with galleries, heads, and bodies, suggesting that they are nutritional symbionts of X. bispinatus. Recently, Saucedo et al. [43] has demonstrated that production of male progeny by females of X. bispinatus is possible when these symbionts are individually offered in artificial media amended with these fungi. Moreover, the indiscriminate association of $X$. bispinatus with these three species suggests that this beetle may not have an obligatory relationship with one specific fungus to fulfill its nutritional requirements, as observed for Dendroctonus brevicomis LeConte [44]. Additional experiments are needed to evaluate the effect of varying amounts of the rearing media's main ingredient on these fungi. Currently, in order to rear $X$. bispinatus, we recommend Medium 1 with avocado sawdust, as described by Castrillo et al. [25]. This medium would yield more female adults. In addition, rearing X. bispinatus in the presence of R. lauricola or other Raffaelea species could facilitate future beetle-fungal symbiosis research.

Previously, it has been documented that other ambrosia beetles (including X. bispinatus) carry R. lauricola [10], the primary nutritional symbiont of X. glabratus $[2,26]$, in their mandibular mycangia. In our experiments, the mycangia of X. bispinatus were scarcely colonized by $R$. lauricola, whereas other Raffaelea species were more frequent and abundant. Our results differ from those of Saucedo et al. [43], in that they found higher numbers of CFUs of the pathogen in X. bispinatus mycangia.

It could be hypothesized that the colonization of the mycangia of any ambrosia beetle is influenced by the first fungi it encounters at the moment when pupae (which do not yet possess mycangia) develop into adults. As the female adults that were employed to establish colonies in the present study did possess mycangia, which were presumably pre-colonized with other symbionts, it is possible that there were reduced opportunities for $R$. lauricola to colonize their mycangia, compared to those in the study of Saucedo et al. [43], in which colonies of X. bispinatus were established with individuals that were exposed to a single symbiont. In the latter situation, it seems probable that there would be an increased opportunity for colonization by $R$. lauricola, especially when new adults of X. bispinatus had only been exposed to that fungus. Clearly, a better understanding of how ambrosia beetles establish and maintain an association with specific symbionts is needed [45].

In our study, the sawdust of two host tree species affected the development and reproduction of $X$. bispinatus. These results are comparable to other studies where ambrosia beetles were artificially reared in different types of sawdust [25]. There is also evidence of differences in host suitability for ambrosia beetles using field collected logs as the rearing substrate. Brar et al. [46] reared X. glabratus on avocado, redbay, and swampbay logs. They found that swampbay was a better host for X. glabratus than the other two species. The results of our study suggest that avocado is a better host for X. bispinatus than silkbay. Since we obtained more progeny on artificial media than Brar et al. [46], artificial media may be a superior method for establishing colonies of ambrosia beetles in laboratory conditions, as opposed to logs.

Foundress females initiated tunneling activities almost immediately after they were introduced into the rearing tubes. Active tunneling was evident by the appearance of copious frass pushed out of the gallery through the entry hole. Frass production continued throughout the life cycle of the beetle and was a sign of colony health. Approximately five days after female introduction, the first galleries were observed along the rearing tube walls, together with fungal growth on the surface of the rearing media. Two weeks after female introduction, the first immature stages were observed in visible galleries or on the surface of the rearing media. The first new adult females were observed approximately 3 weeks after female introduction. These adults remained inside the galleries for approximately 1 week, probably mating with sibling males and helping in colony maintenance [46]. By the fourth week after female introduction, adults started to emerge from the rearing medium and sometimes exhibited an aggressive behavior, chewing underneath the lid or through the plastic walls of the tube. This behavior was typical after 35 days of female introduction, once the colonies 
were crowded and could be related to their natural instinct to disperse at that stage. At the time of dissection (day 40), new adults and the original female were found alongside other developmental stages; new adults were dark brown and very active, whereas the foundress female was typically black and scarcely moving.

The performance of $X$. bispinatus was similar to other ambrosia beetles that were previously reared on artificial media [24-27]. In our study, few females, likely unmated, produced offspring composed of males only; this observation suggests that, like other ambrosia beetles, X. bispinatus possess haplodiploid reproduction: males are haploid derived from unfertilized eggs, and females are diploid derived from fertilized eggs [47]. However, approximately $5 \%$ of broods did not contain males during two consecutive generations. It is unclear whether the females did not produce males at all or whether they died prematurely and were degraded before being tallied. However, male-less broods have also been reported in other ambrosia beetles including Xylossandrus compactus (Eichh.) [48], Xylosandrus germanus (Blandford) [49], Xyleborinus saxesenii (Ratzeburg) [50], and Euwallacea spp. [27].

$X$. bispinatus, like other ambrosia beetles, also exhibits female-biased sex ratios as a consequence of local mate competition (LMC) [51]. Hamilton [51] indicated that the following principles define LMC: the females greatly outnumber the males, development is gregarious, reproduction is arrhenotokous, males are disinclined to emigrate from the colony, every colony has at least one male, males hatch sooner than females and can mate multiple times, mating occurs soon after female eclosion, and females can store sperm after mating. The results of this study verify that $X$. bispinatus meets the first three principles of LMC. However, the fourth principle (one male in every brood) was not met, and the remaining four principles could not be confirmed.

The methods developed by Menocal et al. [28] and tested here may facilitate the study of LMC principles and other aspects of the biology of $X$. bispinatus, such as the interactions with symbiotic fungi. Moreover, laboratory colonies could be used to understand processes that influence $R$. lauricola acquisition by X. bispinatus and the persistence of this association. Laboratory rearing of X. bispinatus on artificial media may greatly facilitate behavioral, physiological, and ecological studies of this important ambrosia beetle.

Acknowledgments: Thanks to Julio Mantilla, Jose Alegría, and Manuela Angel for experiment setup and data collection. Thanks to Hilary Swain for granting permission to collect silkbay wood at Archbold Biological Station. Thanks to James Colee (UF-IFAS-Statistics Department) for his help with the statistical analysis, Waldemar Klassen and Jorge E. Peña (University of Florida) for suggestions to improve the manuscript. This research was in partial the fulfillment of a MS degree for Octavio Menocal from the University of Florida. This work was funded in part by FDACS-SCBG 021757 grant and NIFA grant 2015-51181-24257 to Daniel Carrillo.

Author Contributions: Octavio Menocal, Luisa F. Cruz, and Daniel Carrillo conceived and designed the experiments; Octavio Menocal and Luisa F. Cruz performed the experiments; Octavio Menocal, Luisa F. Cruz, and Daniel Carrillo analyzed the data; Paul E. Kendra, Jonathan H. Crane, Miriam F. Cooperband, and Randy C. Ploetz contributed reagents/materials/analysis tools; Octavio Menocal, Daniel Carrillo and Luisa F. Cruz wrote the paper.

Conflicts of Interest: The authors declare no conflict of interest.

\section{References}

1. Fraedrich, S.W.; Harrington, T.C.; Rabaglia, R.J.; Ulyshen, M.D.; Mayfield, A.E., III; Hanula, J.L.; Eickwort, J.M.; Miller, D.R. A fungal symbiont of redbay ambrosia beetle causes a lethal wilt in redbay and other Lauraceae in the southern United States. Plant Dis. 2008, 92, 215-224. [CrossRef]

2. Harrington, T.C.; Fraedrich, S.W.; Aghayeva, D.N. Raffaelea lauricola, a new ambrosia beetle symbiont and pathogen on the Lauraceae. Mycotaxon 2008, 104, 399-404.

3. Mayfield, A.E., III. Laurel wilt: A serious threat to redbay and other related native plants. Palmetto 2007, 24, 8-11.

4. Fraedrich, S.W.; Harrington, T.C.; Bates, C.A.; Johnson, J.; Reid, L.S.; Best, G.S.; Leininger, T.D.; Hawkins, T.S. Susceptibility to laurel wilt and disease incidence in two rare plant species, pondberry and pondspice. Plant Dis. 2011, 95, 1056-1062. [CrossRef] 
5. Kendra, P.E.; Montgomery, W.S.; Niogret, J.; Pruett, G.E.; Mayfield, A.E., III; MacKenzie, M.; Deyrup, M.A.; Bauchan, G.R.; Ploetz, R.C.; Epsky, N.D. North American Lauraceae: Terpenoid emissions, relative attraction and boring preferences of redbay ambrosia beetle, Xyleborus glabraus (Coleoptera: Curculionidae: Scolytinae). PLoS ONE 2014, 9, e102086. [CrossRef] [PubMed]

6. Hughes, M.A.; Smith, J.A.; Ploetz, R.C.; Kendra, P.E.; Mayfield, A.E., III; Hanula, J.; Hulcr, J.; Stelinski, L.L.; Cameron, S.; Riggins, J.J.; et al. Recovery plan for laurel wilt on redbay and other forest species caused by Raffaelea lauricola and disseminated by Xyleborus glabratus. Plant Health Prog. 2015, 16, 173-210. [CrossRef]

7. Carrillo, D.; Duncan, R.E.; Peña, J.E. Ambrosia beetles (Coleoptera: Curculionidae: Scolytinae) that breed in avocado wood in Florida. Fla. Entomol. 2012, 95, 573-579. [CrossRef]

8. Kendra, P.E.; Owens, D.; Montgomery, W.S.; Narvaez, T.I.; Bauchan, G.R.; Schnell, E.Q.; Tabanca, N.; Carrillo, D. $\alpha$-Copaene is an attractant, synergistic with quercivorol, for improved detection of Euwallacea nr. fornicatus (Coleoptera: Curculionidae: Scolytinae). PLoS ONE 2017, 12, e0179416. [CrossRef] [PubMed]

9. Carrillo, D.; Duncan, R.E.; Ploetz, J.N.; Campbell, A.F.; Ploetz, R.C.; Peña, J.E. Lateral transfer of a phytopathogenic symbiont among native and exotic ambrosia beetles. Plant Pathol. 2014, 63, 54-62. [CrossRef]

10. Ploetz, R.C.; Konkol, J.L.; Narvaez, T.; Duncan, R.E.; Saucedo, R.J.; Campbell, A.; Mantilla, J.; Carrillo, D.; Kendra, P.E. Presence and prevalence of Raffaelea lauricola, cause of laurel wilt, in different species of ambrosia beetle in Florida, USA. J. Econ. Entomol. 2017, 110, 347-354. [PubMed]

11. Atkinson, T.H.; Carrillo, D.; Duncan, R.E.; Peña, J.E. Occurrence of Xyleborus bispinatus (Coleoptera: Curculionidae: Scolytinae) Eichhoff in southern Florida. Zootaxa 2013, 3669, 96-100. [CrossRef] [PubMed]

12. Atkinson, T.H.; Peck, S.B. Annotated checklist of the bark and ambrosia beetles (Coleoptera: Scolytidae) of tropical southern Florida. Fla. Entomol. 1994, 77, 313-329. [CrossRef]

13. Kirkendall, L.R.; Jordal, B.H. The bark and ambrosia beetles (Curculionidae, Scolytinae) of Cocos Island, Costa Rica and the role of mating systems in island zoogeography. Biol. J. Linn. Soc. 2006, 89, 729-743. [CrossRef]

14. Faccoli, M.; Campo, G.; Perrotta, G.; Rassati, D. Two newly introduced tropical bark and ambrosia beetles (Coleoptera: Curculionidae, Scolytinae) damaging figs (Ficus carica) in southern Italy. Zootaxa 2016, 4136, 189-194. [CrossRef] [PubMed]

15. Rabaglia, R.J.; Dole, S.A.; Cognato, A.I. Review of American Xyleborina (Coleoptera: Curculionidae: Scolytinae) occurring North of Mexico, with an illustrated key. Ann. Entomol. Soc. Am. 2006, 99, 1034-1056. [CrossRef]

16. Kendra, P.E.; Niogret, J.; Montgomery, W.S.; Deyrup, M.A.; Epsky, N.D. Cubeb oil lures: Terpenoid emissions, trapping efficacy, and longevity for attraction of redbay ambrosia beetle (Coleoptera: Curculionidae: Scolytinae). J. Econ. Entomol. 2015, 108, 350-361. [CrossRef] [PubMed]

17. Kendra, P.E.; Montgomery, W.S.; Schnell, E.Q.; Deyrup, M.A.; Epsky, N.D. Efficacy of $\alpha$-copaene, cubeb, and eucalyptol lures for detection of redbay ambrosia beetle (Coleoptera: Curculionidae: Scolytinae). J. Econ. Entomol. 2016, 109, 2428-2435. [CrossRef] [PubMed]

18. Six, D.L. Bark beetle-fungus symbioses. In Insect Symbiosis; Bourtzis, K., Miller, T.A., Eds.; CRC Press: Boca Raton, FL, USA, 2003; pp. 97-114.

19. Stephenson, S.L. Changes in a former chesnut-dominated forest after a half century of succession. Am. Midl. Nat. 1986, 116, 173-179. [CrossRef]

20. Storer, A.J.; Wood, D.L.; Gordon, T.R. Modification of coevolved insect-plant interactions by an exotic plant pathogen. Ecol. Entomol. 1999, 24, 238-243. [CrossRef]

21. Brasier, C.M. Ophiostoma novo-ulmi sp. nove., causative agent of current Dutch elm disease pandemics. Mycopathologia, 1991, 115, 151-161. [CrossRef]

22. Ploetz, R.C.; Hulcr, J.; Wingfield, M.J.; de Beer, Z.W. Destructive tree diseases that are associated with ambrosia and bark beetles: Black swan events in tree pathology? Plant Dis. 2013, 95, 856-872. [CrossRef]

23. Saunders, J.L.; Knoke, J.K. Diets for rearing the ambrosia beetle Xyleborus ferrugineus (Fabricius) in vitro. Science 1967, 157, 460. [CrossRef] [PubMed]

24. Mizuno, T.; Kajimura, H. Reproduction of the ambrosia beetle, Xyleborus pfeili (Ratzeburg) (Col., Scolytidae), on semi-artificial diet. J. Appl. Entomol. 2002, 126, 455-462. [CrossRef]

25. Castrillo, L.A.; Griggs, M.H.; Vandenberg, J.D. Brood production by Xylosandrus germanus (Coleoptera: Curculionidae) and growth of its fungal symbiont on artificial diet based on sawdust of different tree species. Environ. Entomol. 2012, 41, 822-827. [CrossRef] 
26. Maner, M.L.; Hanula, J.L.; Braman, K. Rearing redbay ambrosia beetle, Xyleborus glabratus (Coleoptera: Curculionidae: Scolytinae), on semi-artificial media. Fla. Entomol. 2013, 96, 1042-1051. [CrossRef]

27. Cooperband, M.F.; Stouthamer, R.; Carrillo, D.; Eskalen, A.; Thibault, T.; Cossé, A.A.; Castrillo, L.A.; Vanderberg, J.D.; Rugman-Jones, P.F. Biology of two members of the Euwallacea fornicatus species complex (Coleoptera: Curculionidae: Scolytinae), recently invasive in the U.S.A, reared on an ambrosia beetle artificial diet. Agric. For. Entomol. 2016, 18, 223-237. [CrossRef]

28. Menocal, O.; Cruz, L.F.; Kendra, P.E.; Crane, J.H.; Ploetz, R.C.; Carrillo, D. Rearing Xyleborus volvulus (Coleoptera: Curculionidae) on media containing sawdust from avocado or silkbay, with or without Raffaelea lauricola (Ophiostomatales: Ophiostomataceae). Environ. Entomol. 2017, 46, 1275-1283. [CrossRef] [PubMed]

29. Castrillo, L.A.; Griggs, M.H.; Ranger, C.M.; Reding, M.E.; Vandenberg, J.D. Virulence of commercial strains of Beauveria bassiana and Metarhizium brunneum (Ascomycota: Hypocreales) against adult Xylosandrus germanus (Coleoptera: Curculionidae) and impact on brood. Biol. Control 2011, 58, 121-126. [CrossRef]

30. Biedermann, P.H.W.; Klepzig, K.D.; Taborsky, M. Fungus cultivation by ambrosia beetles: Behavior and laboratory breeding success in three Xyleborine species. Environ. Entomol. 2009, 38, 1096-1105. [CrossRef] [PubMed]

31. Dreaden, T.J.; Davis, J.M.; Harmon, C.L.; Ploetz, R.C.; Palmateer, A.J.; Soltis, P.S.; Smith, J.A. Development of multilocus PCR assays for Raffaelea lauricola, causal agent of laurel wilt disease. Plant Dis. 2014, 98, 379-383. [CrossRef]

32. Harrington, T.C.; Aghayeva, D.N.; Fraedrich, S.W. New combinations in Raffaelea, Ambrosiella, and Hyalorhinocladiella, and four new species from the redbay ambrosia beetle, Xyleborus glabratus. Mycotaxon 2010, 111, 337-361. [CrossRef]

33. Paine, T.D.; Raffa, K.F.; Harrington, T.C. Interactions among scolytid bark beetles, their associated fungi, and live host conifers. Ann. Rev. Entomol. 1997, 42, 179-206. [CrossRef] [PubMed]

34. Farrell, B.D.; Sequeira, A.S.; O'Meara, B.C.; Normark, B.B.; Chung, J.H.; Jordal, B.H. The evolution of agriculture in beetles (Curculionidae: Scolytinae and Platypodinae). Evolution 2001, 55, 2011-2027. [CrossRef] [PubMed]

35. Mueller, U.G.; Gerardo, N.M.; Aanen, D.K.; Six, D.L.; Schultz, T.R. The evolution of agriculture in insects. Annu. Rev. Ecol. Evol. Syst. 2005, 36, 563-595. [CrossRef]

36. Beaver, R.A. Insect-fungus relationships in the bark and ambrosia beetles. In Insect-Fungus Interaction; Wilding, N., Collins, N.M., Hammond, P.M., Webber, J.F., Eds.; Academic Press: London, UK, 1989; pp. 121-143.

37. Robinson, S.C.; Tudor, D.; Cooper, P.A. Wood preference of spalting fungi in urban hardwood species. Int. Biodeterior. Biodegr. 2011, 65, 1145-1149. [CrossRef]

38. Abraham, L.D.; Roth, A.; Saddler, J.N.; Breuil, C. Growth, nutrition, and proteolytic activity of the sap-staining fungus Ophiostoma piceae. Can. J. Bot. 1993, 71, 1224-1230. [CrossRef]

39. Käärik, A. Growth and sporulation of Ophiostoma and some other blueing fungi on synthetic media. Symb. Bot. Upsal. 1960, 16, 168.

40. Merrill, W.; Cowling, E.B. Role of nitrogen in wood deterioration: Amount and distribution of nitrogen in fungi. Phytopathology 1966, 56, 1083-1090.

41. French, J.R.; Roeper, R.A. Patterns of nitrogen utilization between the ambrosia beetle Xyleborus dispar and its symbiotic fungus. J. Insect Physiol. 1972, 78, 241-247. [CrossRef]

42. Mizuno, T.; Kajimura, H. Effects of ingredients and structure of semi-artificial diet on the reproduction of an ambrosia beetle, Xyleborus pfeili (Ratzeburg) (Coleoptera: Curculionidae: Scolytinae). Appl. Entomol. Zool. 2009, 44, 363-370. [CrossRef]

43. Saucedo, J.R.; Ploetz, R.C.; Konkol, J.L.; Ángel, M.; Mantilla, J.; Menocal, O.; Carrillo, D. Nutritional symbionts of a putative vector, Xyleborus bispinatus, of the laurel wilt pathogen of avocado, Raffaelea lauricola. Symbiosis 2017. [CrossRef]

44. Bracewell, R.R.; Six, D.L. Experimental evidence of bark beetle adaptation to a fungal symbiont. Ecol. Evol. 2015, 5, 5109-5119. [CrossRef] [PubMed]

45. Bleiker, K.P.; Potter, S.E.; Lauzon, C.R.; Six, D.L. Transport of fungal symbionts by mountain pine beetles. Can. Entomol. 2009, 141, 503-514. [CrossRef]

46. Brar, G.S.; Capinera, J.L.; Kendra, P.E.; McLean, S.; Peña, J.E. Life cycle, development, and culture of Xyleborus glabratus (Coleoptera: Curculionidae: Scolytinae). Fla. Entomol. 2013, 96, 1158-1167. [CrossRef] 
47. Peer, K.; Taborsky, M. Outbreeding depression, but no inbreeding depression in haplodiploid ambrosia beetles with regular sibling mating. Evolution 2005, 59, 317-323. [CrossRef] [PubMed]

48. Entwistle, P.F. Inbreeding and arrhenotoky in the ambrosia beetle Xyleborus compactus (Eichh.) (Coleoptera: Scolytidae). Proc. R. Entomol. Soc. Lond. 1964, 39, 83-88. [CrossRef]

49. Peer, K.; Taborsky, M. Female ambrosia beetles adjust their offspring sex ratio according to outbreeding opportunities for their sons. J. Evol. Biol. 2004, 17, 257-264. [CrossRef] [PubMed]

50. Biedermann, P.H. Observations on sex ratio and behavior of males in Xyleborinus saxesenii Ratzeburg (Scolytinae, Coleoptera). ZooKeys 2010, 56, 253-267. [CrossRef] [PubMed]

51. Hamilton, W.D. Extraordinary sex ratios. Science 1967, 156, 477-488. [CrossRef] [PubMed]

2018 by the authors. Licensee MDPI, Basel, Switzerland. This article is an open access article distributed under the terms and conditions of the Creative Commons Attribution (CC BY) license (http://creativecommons.org/licenses/by/4.0/). 